\title{
The Mediating Role of Customers' Satisfaction on the Effect of CRM on Long-Term Customers Loyalty in the Banking Sector in the Palestinian Territory
}

\author{
Raed A. M. Iriqat ${ }^{1}, \&$ Mohannad A. M. Abu Daqar ${ }^{2}$ \\ ${ }^{1}$ Assistant Professor, Department of Business Administration, Arab American University, Palestine \\ ${ }^{2}$ Master in Strategic Planning \& Fundraising, Arab American University, Palestine \\ Correspondence: Raed A. M. Iriqat, Business Administration Department, Faculty of Administrative and \\ Financial Sciences, Arab American University, P. O. BOX 240, Jenin-West Bank, Palestine. Tel: 970-595386355. \\ E-mail: raed.iriqat@aauj.edu
}

Received: May 19, $2018 \quad$ Accepted: June 19, $2018 \quad$ Online Published: July 27, 2018

doi:10.5539/ass.v14n8p76

URL: https://doi.org/10.5539/ass.v14n8p76

\begin{abstract}
This study aims to investigate the mediating role of customers' satisfaction on the effect of customer relationship management on long-term customers' loyalty in the banking sector in the Palestinian Territory. Using advanced statistical methods. This study supports that there is a high level in implementing the CRM, customers' satisfaction, and long-term customers' loyalty. It showed that these three variables: CRM, customers' satisfaction, and long-term customers' loyalty have a significant role on the Banking sector. CRM and its dimensions, and both of customers' satisfaction, and long-term customers' loyalty are positively significant correlated. Also, finds that there is no role for customers' satisfaction as a mediator variable in enhancing the impact of CRM on long-term customers' loyalty. Moreover, based on SEM the study shows that there is a direct impact of CRM system integration and customers satisfaction on long-term customers' loyalty, whereas there is a direct impact for customers' database and CRM system integration on customers' satisfaction. The scholars find that the Palestinian local banks should pay more efforts to improve their competences to enhance the quality of service and their employees' behavior level. On the other side, they need to keep their customers database updated and to be aligned with the cutting edge technologies to provide better service for customers, which is appropriate and meet their needs by obtaining the accurate information about their preferences in order to build a strong competitive advantage that is hard to imitate, this leads to build a strong relationship with customers.
\end{abstract}

Keywords: customer relationship management, customers satisfaction, long-term customers loyalty, North West Bank, Palestinian Territory

\section{Introduction}

In Palestine, banks play a vital role in the Palestinian local economy; it helps them with the financial aid in order to secure their trade and business fund. Local and foreign banks in Palestinian Territory (PT) as in other countries are providing citizens with the financial facilities that meet their needs and expectations; this leads banks to compete with each other in the local market to provide the best offerings for customers. Thus, banks dedicate the resources and competences to enhance the relationships with customers through decision-making process, marketing, customized services and re-pricing. Customer relationship management (CRM) guides banks in classifying the various segments of customers due to their profitability and the business type. One of the major roles of CRM is to create a better understanding of customers' retention and identifying associated risks with customers' loans. Particularly, customers decide to quit dealing with the bank and respond to other suitable offers according to their needs and retard on their credit. CRM has a major role in the banks by supporting them to capture customers' data and boost the customer information accessibility thus enabling the bank branches to recover their business identity. This study aims to emphasize the importance of building and maintaining good relations with customers which could result in a better customer satisfaction and better CRM system management (Iriqat \& Abu Daqar, 2017a).

CRM aims to retain customers as long-term profitable customers, providing better customer service, selling products and services more effectively, acquire new customers and provide the support and help to salespeople. 
In addition, the top management commitment is mandatory for a superior CRM application in the organization. (Khaligh et al., 2012) show that strategies should be flexible and explicit in order to be aligned with the customers' needs and expectations; these factors are very essential to boom consumer loyalty and profit the organization.

The business owners always looking for improving their businesses, this is a basic feature of the production concept. Customers are looking for the best value in offerings, if organizations and companies don't excel in serving and maintaining a strong relationship with their customers, customers will change their decisions by dealing with organizations that have better service. In this regard, these organizations tend to adopt their best strategies to satisfy customers and to create new customers' base by attracting them with quality products and services in order to shape a strong loyal relationship with them (Long et al., 2013). The most effective CRM application help firms to easily capture the significant marketing and sales information; so, CRM considered as one of the most valuable tool for improving the firm's revenues (Salawdeh, 2009).

In Palestinian Territory, there are 15 operated banks provide their products in the local market, the majority of them are foreign (8 Banks). These banks employ around of 7,000 employees (PMA, 2017). These operated banks using the CRM for managing their interactions and transactions with their users, customers, financial and sales issues. The applied technology is used to manage and assist business activities and processes in the banks. According to Dowling (2002), CRM is a business strategy rather than a technical one.

The main aim of this study is to identify the mediating role of customers' satisfaction on the effect of CRM on long-term customers' loyalty in the Banking sector in North West Bank (NWB) in Palestinian Territory. This study comprised of five sections, introduction, literature review, methodology, the data analysis and the last section is the scholars' conclusion and recommendations. The study consists of six parts as follows: part (1) introduction, part (2) addresses the literature review, whereas part (3) describes the hypotheses, part (4) presents the methodology, part (5) presents data analysis and discussion and part (7) reports the conclusions and recommendations.

\section{Literature Review}

This part of the study displays the outcomes of the theoretical and empirical literature review that discussed and analyzed the role of customer relationship management in enhancing the organizational performance through improving the long-term customers' loyalty and customers' satisfaction. This part consists two sections: (1) Theoretical literature review, and (2) Empirical literature review.

\subsection{Theoretical Literature Review}

\subsubsection{Customer Relationship Management}

Customer relationship management is comparatively a new concept, which arose in 1980s, according to Reinartz \& Kumar (2012) and Hollensen (2015), CRM has two central dimensions, human and business dimensions, human dimension concerns responding and recognizing the human needs whereas the business dimensions are the core components. Karjaluoto et al. (2014) and Muther (2012) demonstrated other five dimensions for CRM which are: solving problems, customers' database, service quality, CRM system integration and employee behavior, these dimensions that identify and satisfy the business needs.

CRM comprises the organization's management interactions with its customers via analyzing their historical data in order to enhance and improve the relationship between the organization and its clients with the aim to enhance the customers' retention rates (Vella and Caruana, 2012). Chan \& Khodakarami (2014) indicate that the objective of using technologies in CRM is to facilitate and automate the business processes in various areas such as marketing, customers support, sales, management and analysis. Furthermore, Galka \& Baran (2013) determine the basic dimensions of CRM as maintenance and the formation of long-loyalty between the firm and its customers, marketing direct techniques, constructing customer interaction and personalizing customer relationship. In addition, Peltier et al. (2013) show that CRM gather customers data from several communication channels as customer feedback and social media so it helps the firm to better understand the needs of customers and how well to satisfy their needs. Mostly, the organizations need to use strategies, practices and technologies in their CRM applications to manage and analyze interactions with its customers. Substantially, the main aim of these principles is to increase the efficiency and reduce the customer interactions costs as well as to increase the decision-making process speed and also to improve the labor efficiency.

\subsubsection{Customer Relationship Management Dimensions}

While the literature on CRM in the banking industry has grown rapidly in the last twenty years, there are limited resources on the specific dimensions of CRM implementation in the industry. However, the broader literature on 
these dimensions offers a rich resource base to build principles for CRM implementation in the banking industry. Mok et al., (2013) for example, identifies the importance of service quality in meeting customer expectations as a vital dimension of CRM, while Moin et al. (2012) identify customer databases as a crucial resource to determining customer behavior and attitudes which are in turn help in meeting their expectations. Further, Alqahtani and Saba (2013) argue that solving the customers and business' problem using these databases is a vital dimension of CRM, with. Zahay et al., (2012) and O'Reilly and Paper (2012) further identifying CRM integration and flexibility in employee behavior due to such integration as two critical CRM dimensions.

In the below table, this study emphasis on five fundamental dimensions of CRM that used by other researchers in several industries. These dimensions significantly enhance customers' satisfaction and loyalty. The scholars concluded the various CRM dimensions in the below-mentioned industries in table 1. According to this table, it is clear that there is a consensus among many researchers to use these CRM dimensions in the banking industry.

Table 1. CRM Dimensions used in various industries

\begin{tabular}{|c|c|c|c|c|}
\hline $\begin{array}{c}\text { CRM } \\
\text { Dimensions }\end{array}$ & Banking industry & $\begin{array}{l}\text { Telecommunications } \\
\text { industry }\end{array}$ & $\begin{array}{l}\text { Hospitability } \\
\text { industry }\end{array}$ & $\begin{array}{c}\text { Healthcare } \\
\text { industry }\end{array}$ \\
\hline $\begin{array}{l}\text { Service } \\
\text { Quality }\end{array}$ & $\begin{array}{l}\text { Chu et al. 2012, Lau et al. } \\
\text { 2013, Hafeez \& Muhammad } \\
\text { 2012, Vera \& Trujillo } 2013\end{array}$ & Rahman 2012 & $\begin{array}{l}\text { Aryee et al. } \\
\text { 2016, Mok et al. } \\
2013\end{array}$ & $\begin{array}{l}\text { Wu \& Ko } \\
2013\end{array}$ \\
\hline $\begin{array}{l}\text { Solving } \\
\text { problems }\end{array}$ & $\begin{array}{l}\text { Steel et al. 2013, Coyle et al. } \\
\text { 2012, Aarikka \& Jaakkola } \\
\text { 2012, DeYoung et al. } 2013\end{array}$ & Alqahtani \& Saba 2013 & Coyle et al. 2012 & $\begin{array}{l}\text { De Mast \& } \\
\text { Lokkerbol } \\
2012\end{array}$ \\
\hline $\begin{array}{l}\text { Customer } \\
\text { Database }\end{array}$ & $\begin{array}{l}\text { Bahrami et al. 2012, Peltier et } \\
\text { al. 2013a, Khan et al. } 2012 \\
\text { Moin et al. (2012), Moro et al. } \\
\text { (2014) }\end{array}$ & Keramati et al. 2014 & Wei et al. 2013 & $\begin{array}{l}\text { Coronel \& } \\
\text { Morris } 2016\end{array}$ \\
\hline $\begin{array}{l}\text { CRM system } \\
\text { integration }\end{array}$ & $\begin{array}{l}\text { Nüesch et al. 2015, Li \& Mao } \\
\text { 2012, Zahay et al. 2012, } \\
\text { Awasthi \& Sangle } 2012\end{array}$ & Soeini \& Jafari 2012 & $\begin{array}{l}\text { Chuang \& Lin } \\
2013 \\
\text { Ku } 2014\end{array}$ & $\begin{array}{l}\text { Cheng \& } \\
\text { Yang } 2013\end{array}$ \\
\hline $\begin{array}{l}\text { Employee } \\
\text { Behavior }\end{array}$ & $\begin{array}{c}\text { Garrido et al. 2014, Alrubaiee } \\
\text { 2012, Grigoroudis et al. 2013, } \\
\text { Adeniji } 2013\end{array}$ & $\begin{array}{c}\text { Abdullateef et al. 2014, } \\
\text { Mokhtar } 2014\end{array}$ & $\begin{array}{c}\text { Kuzu \& Özilhan } \\
2014\end{array}$ & $\begin{array}{l}\text { O'Reilly \& } \\
\text { Paper } 2012\end{array}$ \\
\hline
\end{tabular}

Source: Own

Service Quality described as the action of satisfying the client by meeting their expectations and needs related to the product fully including with regard to (1) price, (2) cost-effectiveness, (3) maintainability, (4) reliability, (5) delivery, (6) availability, (7) appearance, and (8) performance (Wu \& Ko, 2013). Further, for services familiar to the customers, enhanced participation by the customers in the delivery of these services results in increased perceptions of the quality. Aryee et al. (2016) further decompose the service quality concept into five different variables which are reliability, tangibles, assurance, empathy, and responsiveness.

Customer's Database provides insights about the behavior and attitudes of customers to the organization; as well as that the database is the foundation of software used in CRM (Bahrami et al., 2012; Moro et al., 2014; Moin et al., 2012). Keramati et al., (2014) and Khan et al., (2012), in turn, define various crucial attributes of the customer database including that it must be shareable, relevant to its purpose, accurate and reviewed in a timely fashion, up-to-date, transportable to where it is required, and secured from theft and loss. Customer databases that possess these attributes aid the organization in tracking client information and forecasting their needs in the future.

Solving Customer's Problems CRM enables the solving of customer's problems by enhancing the accuracy of opportunity forecasts and the organization's capacity to solve client's issue in the future, while also increasing the organization's ability to match product forecasts with customer's needs (De Mast \& Lokkerbol, 2012; Coyle et al., 2012). Alqahtani and Saba (2013) argue that CRM and its constituent customer database offer organizations the opportunity to solve customer problems, specifically by understanding the organization's current position 
through the generation of vital business metrics and visualization of key performance indicators. Understanding the business metrics and KPIs enables the organization to get an overall view of its sales performance and marketing results, as well as their service resolution standpoint.

Employee's Behavior CRM can play a critical role in driving employee behavioral change, with O'Reilly and Paper (2012) noting that flexible CRM reinforces and supports employee behaviors required to satisfy customers by enabling the employees to recognize and value changing customer needs. CRM enables the organization to consolidate customer information, which can be used to improve the employees' knowledge about changing customer's needs and attitudes. Garrido et al. (2014), Grigoroudis et al. (2013), Adeniji (2013), and Alrubaiee (2012) note that CRM increases employee responsiveness to customers by providing information needed to provide prompt answers to customer questions, and also makes employees more proactive by anticipating customer needs from future forecasts accomplished by the CRM system.

CRM System Integration: The primary purpose of CRM is to manage, track, and organize customer's conversations, activities, and information; which in turn aids the organization's customer service, marketing, and sales team comprehend their clients better (Cheng \& Yang, 2013; Awasthi \& Sangle, 2012; Zahay et al., 2012). According to Li and Mao (2012) and Nüesch et al. (2015), such integration enhances the organization's understanding of changing customer habits and preferences with the aim of developing new products and services to satisfy the emerging customers' needs, provide products and services needed by the customer and improve client retention.

\subsubsection{Customers' Satisfaction}

Customers' satisfaction denotes to the extent to which meeting or surpassing the customers expectation leads to repeat purchases by the customer (Jacka \& Keller, 2013; Rehman, 2012; Abduh, 2012). Kaur et al., 2012, Gazor et al. 2012, Suki et al. 2012 define customer satisfaction as the customer's judgment following their experience with consuming the product or service; or the client's judgment that the service or product provided is what they expected. Additionally, customers' satisfaction increases the customers' lifetime value, it determines the money amount generated through the customer for business firms; whereas retaining the existing customers' costs is lower than acquiring new customers (Sanjuq, 2014; Saad, 2012; Sun \& Kim, 2013). Moreover, Customers' Satisfaction reduces the possibility of negative word of mouth (Kaura, 2013; Hill et al., 2013; Rego et al., 2013).

Customer satisfaction identified by various dimensions mentioned in literature including perceived value (Hsu et al., 2012; Rego et al., 2013), the important needs fulfillment (Steven et al., 2012), effective response (Grissemann \& Stokburger-Sauer; 2012; Kärnä, 2014) and expectations or beliefs confirmation (Dehgan et al., 2012).

\subsubsection{Long-term Customers' Loyalty}

Long-term Customers' Loyalty has several crucial benefits to business organizations, with Setó-Pamies (2012) and Evanschitzky et al. (2012) arguing that customer loyalty leads to customers staying with an organization for a longer time and purchasing more products or services from the organization. Burke (2015) and Malik et al. (2013) in turn posit that organizations benefit from a loyal customer as the latter costs less to serve since they require less support and are familiar with the product or service. Loyal customers, in addition, help to insulate the organization from price wars or competitions, while also acting as ambassadors of the organization's brand (Martinez \& Del Bosque, 2013; Lawfer, 2014). Finally, loyal customers also provide the organization with high quality and honest feedback, which can help improve the organization's products (Blut et al., 2014; Sachs, 2013).

Long-term customers' loyalty has several dimensions that have been mentioned in previous literature reviews, such, decreasing loyalty to other competitors (Burke, 2015; Martinez \& Del Bosque, 2013; Lawfer, 2014), the positive word of mouth (Lowenstein, 2014), the effective logical commitment (Kitapci et al., 2013), and repurchasing (Sachs, 2013; Beneke et al., 2012).

\subsection{Empirical Literature Review}

In this section, this study will discuss the empirical reviews of CRM, customers' satisfaction, and long-term customers' loyalty.

2.2.1 Customer relationship management: The relationship between CRM and the quality of service in the financial services industry have been investigated by Valmohammadi and Beladpas (2014), from the findings, the researchers suggest that bank managers must focus on the communication construct and implement measures to enhance customer's communication while also obtaining information related to the needs of the client. Yao and Khong (2012) approach CRM in the banking sector from a different perspective, investigating whether CRM is still relevant to the banking sector in terms of perceived business performance and customer satisfaction, arguing 
that CRM considers customers as commodities, they found a positive association between CRM and perceived business performance, as well as between CRM and customer satisfaction. CRM decision-making is mainly based on rule-of-thumb heuristics, outweighing such measures as the lifetime value of customers available in analytical approaches of CRM. This highlights existing CRM limitations and the need for more flexibility in CRM practice (Persson \& Ryals, 2014).

The CRM effectiveness investigated by Padmavathy et al. (2012), they found that organizational commitment, process-driven approaches, and reliability are the three pillars of CRM effectiveness which showed positive influence on customer satisfaction, whereas reliability has a positive effect on loyalty and customer satisfaction. Yang (2012) investigated the impact of service capabilities individually and interactively on CRM performance in the financial services industry, the results showed that CRM effectiveness is positively influenced by marketing knowledge, information knowledge, and human resources both individually and interactively. Muro et al. (2013) studied the challenges and the strategical benefits of utilizing the customer relationship management systems in the banking industry, they showed that CRM builds robust loyalty relationship with customer if it will be implemented appropriately and it benefits employees, investors and customers. Iriqat and Abu Daqar (2017a) found that there is a positive and strong relationship between CRM and long-term customers' loyalty. Additionally, CRM system integration has a positive direct impact on long-term customers' loyalty. CRM system integration as one of the CRM dimensions is used in this study.

2.2.2 Long-term Customers' Loyalty: The elements that contribute to long-term customers' loyalty in the service industry were examined by Amin et al. (2012); they found that there is a positive relationship between long-term customers' loyalty and corporate image, switching cost, trust and perceived service quality. Rambocas and Arjoon (2012), investigate customer's loyalty among the millennial generation with a particular focus on internet banking, the researchers determined that the most important influencing factor of loyalty in internet banking from a millennial perspective was perceived relative advantage. Moreover, trust and awareness of benefits offered by internet banking had a moderate impact on customer's loyalty in internet banking. Skowron and Kristensen (2012) more specifically investigated the impact of financial or banking crises on consumer loyalty in the banking industry, the results show that customers in developing countries have lower loyalty levels than those in developed countries and that financial crises have more substantial effect on customers' loyalty in developing countries. Iriqat and Abu Daqar (2017a) investigated the impact of customer relationship management on long-term customers' loyalty in the Palestinian Banks; they demonstrate that there is a direct impact on long-term customers' loyalty and employees' behavior.

The risk of losing customer loyalty was examined by Guillén et al. (2012). Their findings show that customer loyalty fluctuates over time, the authors also found that customer loyalty in short-term organizational-client relationships depends on the viability of the competition and customer value. However, the effect of competition and type of product on customer loyalty declines and becomes less significant with longer-term organizational-client relationships. Ariff et al. (2013) similarly focus on internet banking, in this case exploring the effect of service quality on customers' loyalty among online banking, from the findings, it emerged that customers' satisfaction had a significant positive relationship with customers' loyalty, as well as a significant mediatory role in the relationship between service quality and customers' loyalty. Furthermore, these findings also showed that proper navigation guidance on internet banking websites and website aesthetics also have a positive influence on internet banking customers' loyalty. Rahmani et al. (2014) explored how the quality of banking organization-customer relationships, brand perceptions, and commitment affect long-term customer loyalty. The findings showed that the quality of the relationship between the bank and the customer had a significant association with long-term customer loyalty.

2.2.3 Customers' Satisfaction: The influence of service quality dimension on customers' satisfaction perceptions in the banking industry was examined by Suki et al. (2012, more specifically in the electronic banking sector; the researchers determined that empathy and responsiveness positively influenced customer satisfaction in relation to e-banking services. These results show the importance of enhancing the quality level of services provided to e-banking customers in order to improve their perceptions of gratification with the overall banking service offerings. Chen et al. (2012) delved further into the role of banking service quality on customers' satisfaction, investigating the influence of financial service fairness and quality on banking customers' satisfaction, the researchers found that perceptions of service fairness significantly influence customer satisfaction. Furthermore, Amin et al. (2013) investigated the effects of customers' satisfaction on customers' loyalty, trust, and image perceptions in the Islamic banking industry, the findings determined a significant correlation between customer satisfaction and image perceptions, image perceptions and trust, and trust perceptions and loyalty for the two segments. 
Terpstra \& Verbeeten (2014) further investigated the association between customers' satisfaction, customer value, and customer servicing costs in the banking industry, determining a positive relationship between cost of customer servicing and customers' satisfaction. In addition, there is a positive relationship between customers value and customers satisfaction. A study examined the customer satisfaction levels in conventional banks against Islamic banks by Saad (2012), as well as the association between customer satisfaction and demographic variables. Iriqat \& Abu Daqar (2017b) exploring in their study that CRM and customers satisfaction are positively significant correlated. From the results, it emerged that customers in both conventional and Islamic banks were most satisfied with service quality constructs that included staff efficiency, staff friendliness, and staff competency. Customers satisfaction remains one of the most vital competitive advantage factors in the banking sector, whether in Islamic banking or conventional banking.

\section{Hypotheses}

H0-1: CRM doesn't play a significant role in the banking sector in NWB-PT.

H0-2: Customers' Satisfaction doesn't play a significant role in the banking sector in NWB-PT.

H0-3: Long-term Customers' Loyalty doesn't play a significant role in the banking sector in NWB-PT.

H0-4: CRM dimensions don't directly relate to each other in the banking sector in NWB-PT.

H0-5: CRM dimensions don't directly relate to customers' satisfaction in the banking sector in NWB-PT.

H0-6: CRM dimensions don't directly relate to long-term customers' loyalty in the banking sector in NWB-PT.

H0-7: Perception of Customers' Satisfaction doesn't directly relate to long-term customers' loyalty in the banking sector in NWB-PT.

\section{Methodology}

\subsection{Data Collection and Reliability}

This study used the structured questionnaire to collect primary data from the Banking sector employees in NWB-PT. The structured questionnaire consists of four sections, which are CRM, and its dimensions (customer's database, service quality, employee's behavior, CRM system integration and solving customer's problem), whereas the second and third sections are customers' satisfaction and long-term customers' loyalty respectively. The last section consists of the demographic characteristics about the study respondents. All these parts have been developed based on previous mentioned literature reviews. In addition, reliability of our questionnaire was calculated using Cronbach's Alpha equation. All endogenous and exogenous variables (CRM, customers' satisfaction, and long-term customers' loyalty achieved high coefficient, which are $(0.951),(0.911)$, and $(0.842)$ respectively, and the total effectiveness of the questionnaire is $(0.959)$.

\subsection{Population and Sample size}

The population in this study is limited to all the Banking sector employees in NWB-PT. According to the Palestinian Monetary Authority (2017), there are 15 banks in Palestinian Territory, local and foreign, the number of local banks is 7 and the other is 8 banks. The questionnaire was limited to the NWB-PT employees. These banks employ around (7,000), nearly to 1,960 of them are working banks that located in NWB-PT. Krejcie \& Morgan (1970) equation was used in this study to determine the minimum sample size, so the minimum sample size is 322 respondents, the scholars used a stratified random sample in order to ensure the equitable presentation for all targeted banks in NWB-PT.

\subsection{Conceptual Model}

The main aim of this study is to identify the mediating role of customers' satisfaction on the effect of CRM on long-term customers' loyalty in the banking sector in NWB-PT. Banks have to measure the customers' satisfaction level to enhance the relationship with their customers in order to deliver services and products beyond their expectations to retain them (Winer, 2001). The study conceptual framework is developed from previous mentioned studies. The scholars set the conceptual model to guide their study as the following in Figure 1. 


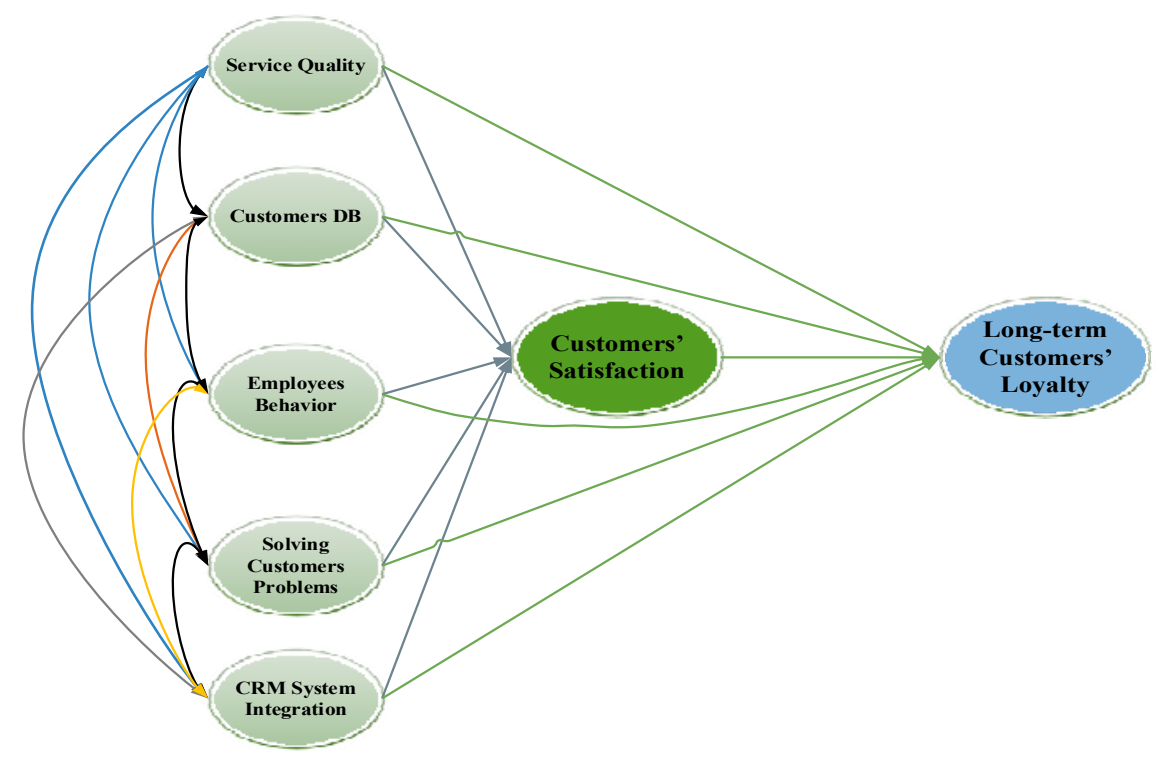

Source: Own

Figure 1. Conceptual Model

\section{Data Analysis}

This section exhibits the results of the above hypotheses using appropriate econometric methods. This study investigates the role of CRM, customers' satisfaction, and long-term customer's loyalty in the Banking sector in NWB-PT by using one sample t-test. And used Pearson correlation test to examine the relationship between exogenous and endogenous variables, and structured equation modeling has been used to examine the mediating role of customers' satisfaction on the effect of CRM on long-term customers' loyalty in the banking sector in NWB-PT.

\section{H0-1: CRM doesn't play a significant role in the banking sector in NWB-PT.}

A one sample t-test was conducted to examine the first null hypothesis (CRM doesn't play a significant role in the banking sector in NWB-PT), with a 95\% level confidence, table 2 shows that the CRM (mean $=4.3942$, $\mathrm{SD}=.34928$ ) was significantly different from 3.67 (cut point), $\mathrm{t}=31.445, \mathrm{p}=0.000$. The results support that the alternative hypothesis which means that CRM plays a significant role in the banking sector in NWB-PT, as same as for all dimensions (service quality, customer's database, employee's behavior, solving customer's problems, and CRM system integration), the $t$ value of previous mentioned dimensions is $(30.585,26.882,22.766,22.912$, and 24.042) respectively at the p-value less than 0.05 . Thus, CRM dimensions are founded significant to enhance the implementation of CRM in Banks and the role that these dimensions play to achieve a better understanding of the customers' needs and how to employ these dimensions to achieve customers' satisfaction and to build long-term loyalty with them.

Table 2. The Results of One Sample T-test for CRM Dimensions

\begin{tabular}{cccccc}
\hline Dimensions & Mean & Std. deviation & Mean differences & T-value & P-value \\
\hline Service Quality & 4.4836 & .40344 & .81361 & 30.585 & .000 \\
Customer's Database & 4.4571 & .44407 & .78714 & 26.882 & .000 \\
Employee's Behavior & 4.4957 & .55000 & .82565 & 22.766 & .000 \\
Solving Customer's Problems & 4.2080 & .35610 & .53797 & 22.912 & .000 \\
CRM System Integration & 4.3975 & .45891 & .72752 & 24.042 & .000 \\
CRM & 4.3942 & .34928 & .72420 & 31.445 & .000 \\
\hline
\end{tabular}

Source: Own

\section{H0-2: Customers' satisfaction doesn't play a significant role in the banking sector in NWB-PT}

A One sample t-test used to examine the second null hypothesis (Customers' satisfaction doesn't play a significant role in the banking sector in NWB-PT), with a 95\% level confidence, table 3 shows that the customers satisfaction (mean $=4.3928, \mathrm{SD}=.43830$ ) was significantly different from 3.67 (cut point), $\mathrm{t}=25.008$, 
$\mathrm{p}=0.000$. The results support that the alternative hypothesis which means that customers' satisfaction plays a significant role in the banking sector in NWB-PT. The employees expressed in the questionnaire that customers' satisfaction items are important for the banks to attract, satisfy, and meet the needs and to decrease the level of competition with other rivals in the same market.

Table 3. The Results of One Sample T-test for Customers' Satisfaction

\begin{tabular}{cccccc}
\hline Dimension & Mean & Std. deviation & Mean differences & T-value & P-value \\
\hline Customers' Satisfaction & 4.3928 & .43830 & .72275 & 25.008 & .000 \\
\hline
\end{tabular}

Source: Own

\section{H0-3: Long-term customers' loyalty doesn't play a significant role in the banking sector in NWB-PT}

One sample t-test used to examine the third hypothesis (Long-term customers' loyalty doesn't play a significant role in the banking sector in NWB-PT), with a 95\% level confidence, table 4 shows that long-term customers' loyalty (mean=4.2917, $\mathrm{SD}=.49004$ ) was significantly different from 3.67 (cut point), $\mathrm{t}=19.240, \mathrm{p}=0.000$. The results support that the alternative hypothesis which means that long-term customers' loyalty plays a significant role in the banking sector in NWB-PT. The most profitable the most loyal customers; this result coincides with other researchers results in this paper, long-term customers' loyalty reflects the bank performance and sustainability and indicates how well the bank perform to keep providing the satisfied services and products to keep customers loyal.

Table 4. The Results of One Sample T-test for Long-term Customers' Loyalty

\begin{tabular}{cccccc}
\hline Dimension & Mean & Std. deviation & Mean differences & T-value & $\mathrm{P}$-value \\
\hline Long-term Customers' Loyalty & 4.2917 & .49004 & .62170 & 19.240 & .000 \\
\hline
\end{tabular}

Source: Own

\section{Fit Model (Path Analysis Model)}

To accept this model, Hu and Bentler (1999) determine the root mean square of approximation (RMSEA) values less than 0.06, the goodness of fit index CFI value of 0.994 or more together with SRMR value less than 0.09. Results of path analysis show that GFI reached 0.994, which is more than 0.96 , also the calculated value of RMSEA is 0.136 . Whereas chi-square is 5.219.AIC 59.219.Figure 2 shows the path analysis model.

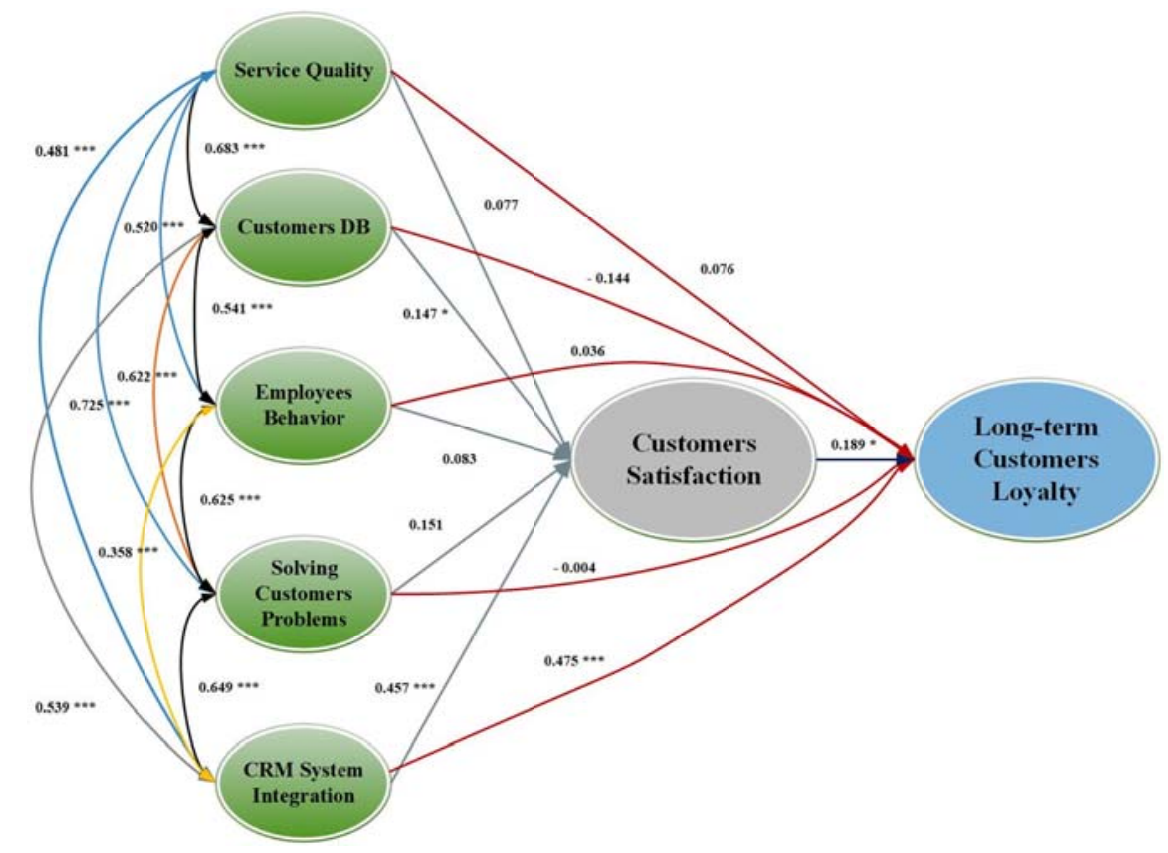

Source: Own

Figure 2. Path Analysis

H0-4: CRM dimensions don't directly relate to each other in the banking sector in NWB-PT

Table 5 presents customer relationship management dimensions are positively correlated to each other, where 
calculated p-value was less than 0.05 . That's mean that the scholars accept the alternative hypothesis and that the CRM dimensions are directly related to each other in the banking sector in NWB-PT. Moreover, Table 5 shows that the quality of service is positively significant correlated to employee's behavior, customers' database, solving customers' problems and CRM system integration in the banking sector in NWB-PT, the standardized direct effect of service quality on the previous mentioned dimensions is $(0.520,0.683,0.725,0.481$ respectively at the p-value less than 0.05). In addition, customers' database is positively significant correlated to employees' behavior, solving customers' problems, and CRM system integration in banking sector in NWB-PT $(0.541,0.622$, 0.539 respectively, P-value less than 0.05 ). Moreover, employee's behavior is positively significant correlated to solving customer's problems and CRM system integration in NWB Banks $(0.625,0.358$ respectively at the p-value less than 0.05 ). Finally, solving customers' problems is positively significant correlated to CRM system integration, the standardized direct effect of solving customers' problems on CRM system integration is 0.649 at p-value less than 0.05 .

Table 5. Path analysis for the Fourth hypothesis

\begin{tabular}{cccccc}
\hline & Path coefficients & Estimate & SE & CR & Sig. \\
\hline Service Quality & Customer's Database & 0.683 & .014 & 8.537 & $* * *$ \\
Service Quality & Employee's Behavior & 0.520 & .016 & 6.978 & $* * *$ \\
Service Quality & Solving Customer's Problems & 0.725 & .012 & 8.883 & $* * *$ \\
Service Quality & CRM System Integration & 0.481 & .014 & 6.561 & $* * *$ \\
Customers Database & Employees Behavior & 0.541 & .018 & 7.202 & $* * *$ \\
Customers Database & Solving Customers Problems & 0.622 & .012 & 7.990 & $* * *$ \\
Customers Database & CRM System Integration & 0.539 & .015 & 7.178 & $* * *$ \\
Employees Behavior & Solving Customers Problems & 0.625 & .015 & 8.022 & $* * *$ \\
Employees Behavior & CRM System Integration & 0.358 & .018 & 5.099 & $* * *$ \\
Solving Customer & & & & & \\
Problems & CRM System Integration & 0.649 & .013 & 8.240 & $* * *$ \\
\hline
\end{tabular}

Source: Own

H0-5: CRM dimensions don't directly relate to customers' satisfaction in the banking sector in NWB-PT.

Table 6 presents that the three CRM dimensions which are: Service quality, Employees' behavior, and solving Customers' Problems aren't significantly related to customers' satisfaction, where calculated p-value was above 0.05 except customers' database and CRM system integration where p-value below 0.05 . That's mean the above hypothesis is accepted only for customer's database and CRM system integration. The scholars found that these two dimensions' customers' database and CRM system integration have a direct effect on customers' satisfaction, because customers' database is the data repository that contains all the data related to customers especially their preferences, so once the bank uses this data in the right manner by achieving their expectations and needs based on it, banks will gain a higher level of customers' satisfaction. However, CRM System Integration manifests that customers always looking to facilitate and manage their relationship with their banks, so the better management will lead to a better satisfaction, integrating the used systems and customers information will result in a better customer service in a real-time and accurate way to provide customers with services.

Table 6. Path analysis for the Fifth hypothesis

\begin{tabular}{clcccc}
\hline \multicolumn{2}{c}{ Path coefficients } & Estimate & SE & CR & Sig. \\
\hline Service Quality & Customers' satisfaction & 0.077 & 075 & 1.118 & .263 \\
Customers Database & Customers' satisfaction & .147 & 063 & 2.292 & .022 \\
Employees Behavior & Customers' satisfaction & 0.083 & .045 & 1.452 & .146 \\
Solving Customers Problems & Customers' satisfaction & .151 & 096 & 1.940 & .052 \\
CRM System Integration & Customers' satisfaction & .457 & 056 & 7.843 & $* * *$ \\
\hline
\end{tabular}

Source: Own

H0-6: CRM dimensions don't directly relate to long-term customers' loyalty in the banking sector in NWB-PT. 
Table 7 presents CRM dimensions aren't significantly related to long-term customers' loyalty, where calculated p-value was above 0.05 except for CRM system integration where p-value below 0.05 . That's mean the sixth hypothesis is accepted only for CRM system integration. In addition, CRM system integration is positively significant correlated to long-term customers' loyalty in the banking sector in NWB-PT, the standardized direct effect of CRM system integration on long-term customers' loyalty is $(0.475$, p-value less than 0.05$)$. The scholars found from the previous hypothesis (5), that CRM System Integration is positively significant correlated to customers' satisfaction, while customers' satisfaction has also a direct effect on long-term customers' loyalty as in hypothesis (7). As mentioned previously, the output of relationship marketing is to satisfy customers in order to achieve the main aim which is the long-term customers' loyalty that leads to a higher profitability.

Table 7. Path analysis for the Sixth hypothesis

\begin{tabular}{clcccc}
\hline \multicolumn{2}{c}{ Path coefficients } & Estimate & SE & CR & Sig. \\
\hline Service Quality & Long-term Customers' Loyalty & 0.076 & 104 & .891 & .373 \\
Customers Database & Long-term Customers' Loyalty & -.144 & 089 & -1.782 & .075 \\
Employees Behavior & Long-term Customers' Loyalty & .036 & .063 & .511 & .609 \\
Solving Customers Problems & Long-term Customers' Loyalty & -.004 & 135 & -.043 & .966 \\
CRM System Integration & Long-term Customers' Loyalty & 0.475 & 087 & 5.814 & $* * *$ \\
\hline
\end{tabular}

Source: Own

H0-7: Perception of customers' satisfaction doesn't directly relate to long-term customers' loyalty in the banking sector in NWB-PT

Table 8 presents customers' satisfaction is positively significant impact on long-term customers' loyalty, the standardized direct effect of customers' satisfaction on long-term customers' loyalty is 0.189 at the p-value less than 0.05. That's mean the alternative hypothesis is accepted. The scholars realized the reason behind the positive direct effect on customers' satisfaction and long-term customers' loyalty that when banks well serve customers and meet their needs they will win their satisfaction, when customers will be satisfied it will create a kind of trust between them and the bank, and then the customers will be loyal to the bank according to the strong relationship had been established between them.

Table 8. Path analysis for the Seventh hypothesis

\begin{tabular}{cccccc}
\hline \multicolumn{2}{c}{ Path coefficients } & Estimate & SE & CR & Sig. \\
\hline Customers' Satisfaction & Long-term Customers' Loyalty & 0.189 & 092 & 2.298 & .022 \\
\hline
\end{tabular}

Source: Own

\section{Conclusion and Recommendations}

The study findings showed that CRM, customer's satisfaction, and long-term customers' loyalty play a significant role in the banking sector in NWB-PT. Moreover, customer relationship management dimensions (quality of service, employee's behavior, customers' database, solving customers' problems and CRM system integration) are positively significant correlated to each other. In addition, Service quality, Employees behavior, and solving Customers' Problems aren't significantly related to customers' satisfaction, whereas, customers' database and CRM system integration are significantly related to customers' satisfaction. The study shows that CRM dimensions aren't significantly related to long-term customers' loyalty, except for CRM system integration, whereas, customers' satisfaction has a positive significant impact on long-term customers' loyalty.

This paper recommended that: Bankers could develop customer retention strategies through offering higher levels of service quality through making poll results about the level of services provided by the bank itself compared with other banks. Some of these strategies is to anticipate the customers' behaviors through analyzing their data and to be aware of the new trends and how it could be applied using the available technology, applications, systems and physical equipment. Through watching customer's data, the bank will be able to handle and respond to any change in the customers' behaviors and their needs and how best to satisfy their needs with the least cost. Also, customers' loyalty program could be applied to improve the customers' perception of the banks with a positive image and feedback.

Banks could also keep in touch with their customers to determine their current needs by offering them services that meet their needs such as online services like e-banking services and mobile applications. In addition, there are some services that may attract customers and retain them by introducing the international money transfer 
services as Western Union and MoneyGram into their online banking services. Banks need to equip and improve these online tools daily and operational services as much as they can, so, customers can submit their services and then these services transferred to the exact branch to be processed there and then sending an acknowledgment message for the customer about his request order. Furthermore, the banks advised to upgrade their customers' database as it is the source of information to solve their problems and to find the best offers that fit their needs and expectations. The customers' database help banks to periodically review and monitor the customers' complaints and problems in order to improve their customer service experience and practice.

The banks need to train and empower its employees with the last cutting-edge skills and knowledge to better serving their customers and build a robust relationship with them. Banks could pay attention to administrative employees because these employees are more effective in maintaining long-term customers' loyalty.

\section{References}

Abduh, M., Kassim, S., \& Dahari, Z. (2012). Customer gratification and switching behavior in Islamic banking: Evidence from Indonesia. School of Doctoral Studies (European Union) Journal, (4), 209-215

Adeniji, A. A., Osibanjo, A. O., \& Abiodun, A. J. (2013). Organisational Change and Human Resource Management Interventions: an Investigation of the Nigerian Banking Industry. Serbian Journal of Management, 8(2), 2-16

Alqahtani, F. A., \& Saba, T. (Alqahtani, F. A., \& Saba, 2013). Impact of Social Networks on Customer Relation Management (CRM) in Prospectus of Business Environment. Journal of American Sciences, 9(7), 480-486

Alrubaiee, L. (2012). Exploring the relationship between ethical sales behavior, relationship quality, and customer loyalty. International Journal of Marketing Studies, 4(1), 7-18. https://doi.org/10.5539/ijms.v4n1p7

Amin, S. M., Ahmad, U. N. U., \& Hui, L. S. (2012). Factors contributing to customer loyalty towards telecommunication service provider. Procedia-Social and Behavioral Sciences, 40, 282-286. https://doi.org/10.1016/j.sbspro.2012.03.192

Ariff, M. S. M., Yun, L. O., Zakuan, N., \& Ismail, K. (2013). The impacts of service quality and customer gratification on customer loyalty in internet banking. Procedia-Social and Behavioral Sciences, 81, 469-473. https://doi.org/10.1016/j.sbspro.2013.06.462

Aryee, S., Walumbwa, F. O., Seidu, E. Y., \& Otaye, L. E. (2016). Developing and leveraging human capital resource to promote service quality: Testing a theory of performance. Journal of management, 42(2), 480-499. https://doi.org/10.1177/0149206312471394

Authority, PMA. (n. d.). The Palestine... Retrieved August 7, 2017, from http://www.pma.ps/

Awasthi, P., \& Sangle, P. S. (2012). Adoption of CRM technology in multichannel environment: A review (2006-2010). Business Process Management Journal, 18(3), 445-471. https://doi.org/10.1108/14637151211232641

Bahrami, M., Ghorbani, M., \& Arabzad, S. M. (2012). Information technology (IT) as an improvement tool for customer relationship management (CRM). Procedia-Social and Behavioral Sciences, 41, 59-64. https://doi.org/10.1016/j.sbspro.2012.04.008

Baran, R. J., \& Galka, R. J. (2013). CRM: the foundation of contemporary marketing strategy. London: Routledge. https://doi.org/10.1016/j.crma.2013.09.021

Beneke, J., Hayworth, C., Hobson, R., \& Mia, Z. (2012). Examining the effect of retail service quality dimensions on customer satisfaction and loyalty: The case of the supermarket shopper. Acta Commercii, 12(1), 27-43. https://doi.org/10.4102/ac.v12i1.129

Binsar, P., Anggia, F., \& Panjaitan, H. (2014). Analysis of Customer Loyalty through Total Quality Service, Customer Relationship Management and Customer Satisfaction. International Journal of Evaluation and Research in Education, 3(3), 142-151

Blut, M., Beatty, S. E., Evanschitzky, H., \& Brock, C. (2014). The impact of service characteristics on the switching costs-customer loyalty link. Journal of Retailing, 90(2), 275-290. https://doi.org/10.1016/j.jretai.2014.04.003

Burke, J. (2015). Relationship Aspect Marketing: Building Customer Loyalty in the Internet Age. Aberdeen: Silver Lake Pub. 
Chen, H. G., Yu-Chih Liu, J., Shin Sheu, T., \& Yang, M. H. (2012). The impact of financial services quality and fairness on customer satisfaction. Managing Service Quality: An International Journal, 22(4), 399-421. https://doi.org/10.1108/09604521211253496

Cheng, L. Y., \& Yang, C. W. (2013). Conceptual analysis and implementation of an integrated CRM system for service providers. Service Business, 7(2), 307-328. https://doi.org/10.1007/s11628-012-0160-z

Coyle, J. R., Smith, T., \& Platt, G. (2012). "I'm here to help" How companies' microblog responses to consumer problems influence brand perceptions. Journal of Research in Interactive Marketing, 6(1), 27-41. https://doi.org/10.1108/17505931211241350

De Mast, J., \& Lokkerbol, J. (2012). An analysis of the Six Sigma DMAIC method from the perspective of problem solving. International Journal of Production Economics, 139(2), 604-614. https://doi.org/10.1016/j.ijpe.2012.05.035

Dehghan, A., Zenouzi, B., \& Albadvi, A. (2012). An Investigation on the Relationship between Service Quality and Customer Satisfaction: In the Case of CCG CO. International Business Research, 5(1), 3-21

Dowling, G. (2002). Customer Relationship Management: In B2C Markets, Often Less Is More. California Management Review, 44(3), 121-137. https://doi.org/10.2307/41166134

Evanschitzky, H., Ramaseshan, B., Woisetschläger, D. M., Richelsen, V., Blut, M., \& Backhaus, C. (2012). Consequences of customer loyalty to the loyalty program and to the company. Journal of the Academy of Marketing Science, 40(5), 625-638. https://doi.org/10.1007/s11747-011-0272-3

Garrido, A., Lockett, N., \& García-Morales, V. (2014). Paving the way for CRM success: The mediating role of knowledge management and organizational commitment. Information \& Management, 51(8), 1031-1042. https://doi.org/10.1016/j.im.2014.06.006

Gazor, H., Nemati, B., Ehsani, A., \& Ameleh, K. (2012). Analyzing effects of service encounter quality on customer gratification in banking industry. Management Science Letters, 2(3), 859-868. https://doi.org/10.5267/j.msl.2011.11.011

Graf, M., Schlegelmilch, B. B., Mudambi, S. M., \& Tallman, S. (2013). Outsourcing of customer relationship management: Implications for customer satisfaction. Journal of Strategic Marketing, 21(1), 68-81. https://doi.org/10.1080/0965254X.2012.734844

Grigoroudis, E., Tsitsiridi, E., \& Zopounidis, C. (2013). Linking customer satisfaction, employee appraisal, and business performance: an evaluation methodology in the banking sector. Annals of Operations Research, 205(1), 5-27. https://doi.org/10.1007/s10479-012-1206-2

Grissemann, U. S., \& Stokburger-Sauer, N. E. (2012). Customer co-creation of travel services: The role of company support and customer satisfaction with the co-creation performance. Tourism Management, 33(6), 1483-1492. https://doi.org/10.1016/j.tourman.2012.02.002

Guillén, M., Nielsen, J. P., Scheike, T. H., \& Pérez-Marín, A. M. (2012). Time-varying effects in the analysis of customer loyalty: A case thesis in insurance. Expert Systems with Applications, 39(3), 3551-3558. https://doi.org/10.1016/j.eswa.2011.09.045

Hashem, T. N. (2012). The Impact of Customer Relationship Marketing On Customers Satisfaction for the Banking Industry in Jordan. International Journal of Management Cases, 14(4), 142-153. https://doi.org/10.5848/APBJ.2012.00093

Hill, N., Brierley, J., \& MacDougall, R. (2013). How to measure customer satisfaction. Burlington, VT, USA: Gower

Hollensen, S. (2015). Marketing management: A relationship approach. Upper Saddle River: Pearson Education

Hsu, C. L., Chang, K. C., \& Chen, M. C. (2012). The impact of website quality on customer satisfaction and purchase intention: perceived playfulness and perceived flow as mediators. Information Systems and e-Business Management, 10(4), 549-570. https://doi.org/10.1007/s10257-011-0181-5

Hu, L. \& Bentler, P. (1999). Cutoff criteria for fit indices in covariance structure analysis: Conventional criteria

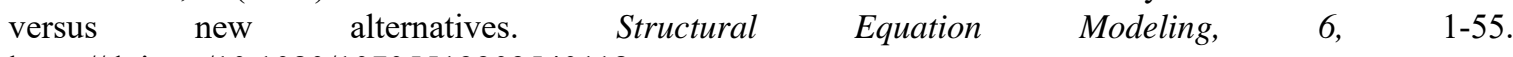
https://doi.org/10.1080/10705519909540118

Iriqat, R. A., \& Abu Daqar, M. A. (2017a). The Impact of Customer Relationship Management on Long-term Customers' Loyalty in the Palestinian Banking Industry. International Business Research, 10(11), 139. 
https://doi:10.5539/ibr.v10n11p139

Iriqat, R. A., \& Daqar, M. A. (2017b). The Role of Customer Relationship Management on Enhancing the Customers' Satisfaction in the Banks in Palestine. Modern Applied Science, 11(12), 84. https://doi:10.5539/mas.v11n12p84

Jacka, J. M., \& Keller, P. J. (2013). Business process mapping: Improving customer satisfaction. Hoboken, N.J: Wiley

Karjaluoto, H., Töllinen, A., Pirttiniemi, J., \& Jayawardhena, C. (2014). Intention to use mobile customer relationship management systems. Industrial Management \& Data Systems, 114(6), 966-978. https://doi.org/10.1108/IMDS-11-2013-0480

Kärnä, S. (2014). Analysing customer satisfaction and quality in construction-the case of public and private customers. Nordic journal of surveying and real estate research, 2(1), 112-116.

Kaur, H., \& Soch, H. (2012, October). Validating Antecedents of Customer Loyalty for Indian Cell Phone Users. Retrieved August 01, 2017, from http://www.vikalpa.com/

Kaura, V. (2013). Antecedents of customer satisfaction: a thesis of Indian public and private sector banks. International Journal of Bank Marketing, 31(3), 167-186. https://doi.org/10.1108/02652321311315285

Keramati, A., Jafari-Marandi, R., Aliannejadi, M., Ahmadian, I., Mozaffari, M., \& Abbasi, U. (2014). Improved churn prediction in telecommunication industry using data mining techniques. Applied Soft Computing, 24, 994-1012. https://doi.org/10.1016/j.asoc.2014.08.041

Khaligh, A., Miremadi, A., \& Aminilari, M. (2012). The Impact of eCRM on Loyalty and Retention of Customers in Iranian Telecommunication Sector. International Journal of Business Management, 7(2), $150-162$.

Khan, A., Ehsan, N., Mirza, E., \& Sarwar, S. Z. (2012). Integration between customer relationship management (CRM) and data warehousing. Procedia Technology, 1, 239-249. https://doi.org/10.1016/j.protcy.2012.02.050

Khodakarami, F., \& Chan, Y. E. (Khodakarami, F., \& Chan, 2014). Exploring the role of customer relationship management (CRM) systems in customer knowledge creation. Information \& Management, 51(1), 27-42. https://doi.org/10.1016/j.im.2013.09.001

Kitapci, O., Taylan Dortyol, I., Yaman, Z., \& Gulmez, M. (2013). The paths from service quality dimensions to customer loyalty: An application on supermarket customers. Management Research Review, 36(3), 239-255. https://doi.org/10.1108/01409171311306391

Krejcie, R. V., \& Morgan, D. W. (1970).Determining Sample Size for Research Activities. Educational and Psychological Measurement. 30, 607-610 (Sample Size). https://doi.org/10.1177/001316447003000308

Kumar, V., \& Reinartz, W. (2012). Customer relationship management: Concept, strategy, and tools. Berlin: Springer Science \& Business Media. https://doi.org/10.1007/978-3-642-20110-3

Lawfer, M. R. (2014). Why customers come back: How to create lasting customer loyalty. Franklin Lakes, NJ: Career Press.

Li, L., \& Mao, J. Y. (2012). The effect of CRM use on internal sales management control: An alternative mechanism to realize CRM benefits. Information \& Management, 49(6), 269-277. https://doi.org/10.1016/j.im.2012.09.005

Long, C. S., Khalafinezhad, R., Ismail, W. K., \& Rasid, S. Z. (2013). Impact of CRM Factors on Customer Satisfaction and Loyalty. Asian Social Science, 9(10). https://doi.org/10.5539/ass.v9n10p247

Lowenstein, M. W. (2014). The customer loyalty pyramid. Westport, Conn: Quorum

Malik, M. E., Ghafoor, M. M., Hafiz, K. I., Riaz, U., Hassan, N. U., Mustafa, M., \& Shahbaz, S. (2013). Importance of brand awareness and brand loyalty in assessing purchase intentions of consumer. International Journal of Business and Social Science, 4(5), 43-55

Martínez, P., \& Del Bosque, I. R. (2013). CSR and customer loyalty: The roles of trust, customer identification with the company and satisfaction. International Journal of Hospitality Management, 35, 89-99. https://doi.org/10.1016/j.ijhm.2013.05.009

Moin, K. I., \& Ahmed, D. Q. B. (2012). Use of data mining in banking. International Journal of Engineering Research and Applications, 2(2), 738-742. 
Mok, C., Sparks, B., \& Kadampully, J. (2013). Service quality management in hospitality, tourism, and leisure. London: Routledge

Moro, S., Cortez, P., \& Rita, P. (2014). A data-driven approach to predict the success of bank telemarketing. Decision Support Systems, 62, 22-31. https://doi.org/10.1016/j.dss.2014.03.001

Muro, M. B., Magutu, P. O., \& Getembe, K. N. (2013). The strategic benefits and challenges in the use of customer relationship management systems among commercial banks in Kenya. European Scientific Journal, ESJ, 9(13), 34-49.

Muther, A. (2012). Customer relationship management: Electronic customer care in the new economy. Berlin: Springer Science \& Business Media.

Nüesch, R., Alt, R., \& Puschmann, T. (2015). Hybrid customer interaction. Business \& Information Systems Engineering, 57(1), 73-82. https://doi.org/10.1007/s12599-014-0366-9

O'Reilly, K., \& Paper, D. (2012). CRM and retail service quality: front-line employee perspectives. International Journal of Retail \& Distribution Management, 40(11), 865-881. https://doi.org/10.1108/09590551211267610

Padmavathy, C., Balaji, M. S., \& Sivakumar, V. J. (2012). Measuring effectiveness of customer relationship management in Indian retail banks. International Journal of Bank Marketing, 30(4), 246-266. https://doi.org/10.1108/02652321211236888

Peltier, J., Zahay, D., \& Krishen, A. S. (2013). A hierarchical IMC data integration and measurement framework and its impact on CRM system quality and customer performance. Journal of Marketing Analytics, 1(1), 32-48. https://doi.org/10.1057/jma.2013.1

Persson, A., \& Ryals, L. (2014). Making customer relationship decisions: Analytics v rules of thumb. Journal of Business Research, 67(8), 1725-1732. https://doi.org/10.1016/j.jbusres.2014.02.019

Rahmani, L., Firoozbakht, Z., \& Taghipoor, A. (2014). Service quality, relationship quality and customer loyalty (Case thesis: Banking industry in Iran). Open Journal of Social Sciences, 2(4), 262-267. https://doi.org/10.4236/jss.2014.24028

Rambocas, M., \& Arjoon, S. (2012). Using diffusion of innovation theory to model customer loyalty for Internet banking: A TT millennial perspective. International Journal of Business and Commerce, 1(8), 1-14.

Rego, L. L., Morgan, N. A., \& Fornell, C. (2013). Reexamining the market share-customer satisfaction relationship. Journal of Marketing, 77(5), 1-20. https://doi.org/10.1509/jm.09.0363

Rehman, A. (2012). Customer satisfaction and service quality in Islamic banking: A comparative thesis in Pakistan, United Arab Emirates and United Kingdom. Qualitative Research in Financial Markets, 4(2/3), 165-175. https://doi.org/10.1108/17554171211252501

Saad, N. M. (2012). Comparative analysis of customer gratification on Islamic and conventional banks in Malaysia. Asian Social Science, 8(1), 73-88.

Sachs, J. (2013). Customer loyalty. Place of publication not identified: Motivational Press, Inc.

Salawdeh, H. (2009). CRM and Relationship Profitability in Banking. Corporate Technology Solutions. Retrieved August 1, 2017, from https://www.consult-cts.com/why-cts/.../1_75f69442c71061e1ae992492da3d5424

Sanjuq, G. (2014). The impact of service quality delivery on customer gratification in the banking sector in Riyadh, Saudi Arabia. International Journal of Business Administration, 5(4), 77-89. https://doi.org/10.5430/ijba.v5n4p77

Setó-Pamies, D. (2012). Customer loyalty to service providers: examining the role of service quality, customer satisfaction and trust. Total Quality Management \& Business Excellence, 23(11-12), 1257-1271. https://doi.org/10.1080/14783363.2012.669551

Sin, L. Y. M., Tse, A. C. B., \& Yim, F. H. K. (2005). CRM: Conceptualization and scale development. European Journal of Marketing, 39(11/12), 1264-1290. https://doi.org/10.1108/03090560510623253

Skowron, L., \& Kristensen, K. (2012). The impact of the recent banking crisis on customer loyalty in the banking sector: Developing versus developed countries. The TQM Journal, 24(6), 480-497. https://doi.org/10.1108/17542731211270052

Steven, A. B., Dong, Y., \& Dresner, M. (2012). Linkages between customer service, customer satisfaction and 
performance in the airline industry: Investigation of non-linearities and moderating effects. Transportation Research Part E: Logistics and Transportation Review, 48(4), 743-754. https://doi.org/10.1016/j.tre.2011.12.006

Suki, N. M., Tan, C., Ping, Y., \& Suki, N. M. (2012). Service quality dimension effects on customer gratification towards e-banking. Interdisciplinary journal of contemporary research in business, 4(4), 741-751.

Sun, K. A., \& Kim, D. Y. (2013). Does customer satisfaction increase firm performance? An application of American Customer Satisfaction Index (ACSI). International Journal of Hospitality Management, 35, 68-77. https://doi.org/10.1016/j.ijhm.2013.05.008

Terpstra, M., \& Verbeeten, F. H. (2014). Customer satisfaction: cost driver or value driver? Empirical evidence from the financial services industry. European Management Journal, 32(3), 499-508. https://doi.org/10.1016/j.emj.2013.07.001

Valmohammadi, C., \& Beladpas, M. (2014). Customer relationship management and service quality, a survey within the banking sector. Industrial and Commercial Training, 46(2), 77-83. https://doi.org/10.1108/ICT-08-2013-0056

Vella, J., \& Caruana, A. (2012). Encouraging CRM systems usage: a thesis among bank managers. Management Research Review, 35(2), 121-133. https://doi.org/10.1108/01409171211195152

Wang, C. Y., \& Wu, L. W. (2012). Customer loyalty and the role of relationship length. Managing Service Quality: An International Journal, 22(1), 58-74. https://doi.org/10.1108/09604521211198119

Wang, M. L. (2013). Implementing CRM in nursing homes: the effects on resident satisfaction. Managing Service Quality: An International Journal, 23(5), 388-409. https://doi.org/10.1108/MSQ-08-2012-0086

Winer, R. (2001). A framework for customer relationship management. California Management Review, 43(4), 89-105. https://doi.org/10.2307/41166102

Wu, H. C., \& Ko, Y. J. (2013). Assessment of service quality in the hotel industry. Journal of Quality Assurance in Hospitality \& Tourism, 14(3), 218-244. https://doi.org/10.1080/1528008X.2013.802557

Yang, Y. F. (2012). Service capabilities and customer relationship management: an investigation of the banks in Taiwan. The Service Industries Journal, 32(6), 937-960. https://doi.org/10.1080/02642069.2010.545394

Yao, H. I., \& Khong, K. W. (2012). Customer relationship management: is it still relevant to commercial banks in Taiwan?. International Journal of Business and Management, 7(1), 151-160.

Zahay, D., Peltier, J., \& Krishen, A. S. (2012). Building the foundation for customer data quality in CRM systems for financial services firms. Journal of Database Marketing \& Customer Strategy Management, 19(1), 5-16. https://doi.org/10.1057/dbm.2012.6

\section{Copyrights}

Copyright for this article is retained by the author(s), with first publication rights granted to the journal.

This is an open-access article distributed under the terms and conditions of the Creative Commons Attribution license (http://creativecommons.org/licenses/by/4.0/). 